\title{
Natural Resources and Institutional Development
}

\section{David Wiens}

\begin{abstract}
Recent work on the resource curse argues that the effect of resource wealth on development outcomes is a conditional one: resource dependent countries with low quality institutions are vulnerable to a resource curse, while resource dependent countries with high quality institutions are not. But extant models neglect the ways in which the inflow of resource revenue impacts the institutional environment itself. In this paper, I present a formal model to show that where domestic institutions do not limit state leaders' discretion over policy prior to becoming fiscally reliant on resources, those leaders have little incentive in the wake of resource windfalls to establish institutional mechanisms that limit their discretion. Importantly, this shows that simple calls for domestic institutional reform are unlikely to be effective. Among other things, future prescriptions to mitigate the resource curse must focus on decreasing rulers' fiscal reliance on resources.
\end{abstract}

\section{INTRODUCTION}

Recent theoretical and empirical work on the resource curse highlights the importance of the nature of domestic institutions for explaining the connection between point-source resource wealth and development outcomes. ${ }^{1}$ At bottom, the effect of resource revenue on development is a conditional one: resource dependent countries with low quality institutions are vulnerable to a resource curse, while resource dependent countries with high quality institutions can escape the deleterious effects of resource wealth (see, among others, Al-Ubaydli, 2012; Andersen and Aslaksen, 2008; Boschini et al., 2007; Mehlum et al., 2006; Robinson et al., 2006; Ross, 2012).

Existing theoretical models share a tendency to treat institutions as exogenous - they typically investigate the ways in which existing institutions condition the incentives generated by resource rents, but rarely consider the ways in which resource rents affect

AUTHOR'S NOTE. Earlier versions of this paper were presented at the Australian National University and University of Michigan; thanks to those audiences for helpful discussion. I am particularly grateful to Bill Clark, Mike Miller, Leif Wenar, anonymous referees, and the editor for helpful comments and suggestions.

1 On the importance of "point-source" versus "diffuse" resources, see Le Billon (2001) (cf. Snyder and Bhavnani's [2005] distinction between "nonlootable" and "lootable" resources). Point-source (nonlootable) resources include oil, gas, copper, or kimberlite diamonds; diffuse (lootable) resources include alluvial diamonds or timber.

(C) 2013 David Wiens

To appear in Journal of Theoretical Politics. 


\section{David Wiens}

the determinants underlying the nature of the institutional environment itself. $^{2}$ This misleadingly suggests that overcoming the deleterious economic effects of resource wealth is simply a matter of changing the institutional environment (cf. Bell et al., 2010; Humphreys et al., 2007). But this neglects an important dimension of the problem posed by resource wealth.

In this paper, I present a formal model to show that the standard institutional stories neglect the possibility that the persistence of curse-fostering institutions is endogenous to the resource curse. My analysis is based on a more general model of domestic competition over political outcomes. I aim to identify the underlying conditions to which governance and economic performance are generally sensitive. The model reduces these outcomes to two parameters: rulers' dependence on citizens for support and the credibility of supporters' exit threats. Having shown that development outcomes are sensitive to these parameters, I then theorize about how resource revenue affects them. The model implies that the nature of institutions in resource dependent countries is path dependent. In countries where institutional mechanisms to constrain the ruler's policy discretion are absent prior to the onset of resource dependence, resource revenues undermine any impetus to establish "good" institutions in their wake and serve to stabilize "bad" institutions. When this is the case, stable democratic institutions and long-term economic prosperity should be highly unlikely to emerge in resource dependent countries. However, where institutional mechanisms to constrain the ruler's policy discretion have been consolidated prior to resource dependence, then the ruler uses resource income to advance citizens' general interests and "good" institutions remain intact. In these cases, we have no reason to expect resource revenues to undermine democracy or long-term economic prosperity.

The subtlety introduced by the model is critical for getting our prescriptions correct. Standard prescriptions for addressing the resource curse press for various domestic institutional reforms. But if the more subtle story is correct - if curse-fostering institutions persist in the wake of continued resource dependence - then standard prescriptions will likely be ineffective. The standard institutional explanations claim that the resource curse arises because domestic institutions encourage fiscal irresponsibility, corruption, or unaccountability. But institutions that encourage irresponsibility, corruption, or unaccountability also inhibit voluntary institutional reform. If this is true, then it is futile to first identify, for example, lack of fiscal accountability to citizens as a key cause of the resource curse and then prescribe that the state establish mechanisms to ensure citizen oversight of resource transactions (cf. Kolstad and Wiig, 2009b).

2 Although this is beginning to change; cf. Al-Ubaydli (2012); Bueno de Mesquita and Smith (2010); Collier and Hoeffler (2009). 


\section{INSTITUTIONS AND THE RESOURCE CURSE}

Let's begin with some definitions. Let "ruler" denote the individual or group who retains ultimate power to implement or block the implementation of policy, as well as the loyal bureaucrats to whom particular tasks are delegated. ${ }^{3}$ We can distinguish between two broad types of domestic institutional structures. Generally, restrictive institutions empower (formally or informally) a broad coalition of citizens to effectively check the formation and implementation of policy; unrestrictive institutions, in contrast, afford the ruler wide latitude to implement policy without having to consult citizens' general interests. Roughly, restrictive institutions limit a ruler's discretion over policy decisions, while unrestrictive institutions fail to limit a ruler's discretion over policy decisions. Of particular importance here is the extent of a ruler's discretion over resource revenue. Unrestrictive institutions afford rulers wide latitude to use resource revenue as they see fit, whereas restrictive institutions empower citizens to oversee the use of resource revenue.

Stated generally, the core propositions of standard institutional explanations are these:

The economic resource curse: Unrestrictive domestic institutions permit a ruler to allocate resource revenue in ways that inhibit sustainable broad-based economic productivity.

The political resource curse: Unrestrictive domestic institutions permit a ruler to allocate resource revenue in ways that undermine stable executive accountability to a broad coalition of citizens.

Debate remains over the precise mechanisms encoded by the italicized phrases, but there does seem to be widespread agreement that the curse is a result of various policy failures fostered by unrestrictive institutions. Initially, development economists tended to focus on various macroeconomic policy failures - lack of sectoral diversification (lack of investment in internationally competitive manufacturing in particular); overconsumption of resource revenue and failure to smooth spending, thereby increasing budget vulnerability to price volatility; and underinvestment in education and health care (Auty, 2001; Gelb and Associates, 1988; Sachs and Warner, 2001). But macroeconomic policy failure is a political outcome. Hence, the literature now largely focuses on the contribution of political factors to the curse. These include: the incumbent's increased capacity to consolidate political power through repression and patronage (Bueno de Mesquita and Smith, 2010;

3 Where convenience dictates, I refer to rulers using male pronouns. 


\section{David Wiens}

Jensen and Wantchekon, 2004; Robinson et al., 2006; Smith, 2006; Wantchekon, 2002); a political economy rife with corruption and rent-seeking, which diverts human and financial capital from economically productive uses (Bhattacharyya and Hodler, 2010; Boschini et al., 2007; Mehlum et al., 2006; Torvik, 2002); and lack of transparency in resource sales and revenue spending (Kolstad and Wiig, 2009a; Williams, 2011). One issue of special focus has been the negative effect of resource wealth on a ruler's need to raise revenue via taxation (see, among others, Karl, 1997; Mahdavy, 1970; Ross, 2001). Without the need to elicit citizens' tax compliance, political leaders need not negotiate with citizens over policy. Further, low tax rates alleviate social pressures that might otherwise provoke demands for government accountability (Ross, 2004). Consequently, leaders who receive a sizeable income from resource extraction have few incentives to accept institutional limits on their exercise of political power. Relatedly, resource revenues might enable governments to appease citizens' demands for redistribution, diminishing redistributive pressures that could produce calls for democracy (Dunning, 2008; Morrison, 2007, 2009).

These standard institutional explanations get something fundamentally right: the resource curse is ultimately a story about the incentives generated by the domestic political economy into which resource revenue flows; it is a story about the extent to which domestic political institutions enable rulers to pursue their own interests while disregarding ordinary citizens' rights and well-being. However, standard analyses rarely consider the extent to which the persistence of unrestrictive institutions is endogenous to the resource curse. What if the incentive structure that generates overconsumption and underinvestment, corruption and patronage, unaccountability and repression also inhibits voluntary establishment of the institutional mechanisms required to avoid these ills? Upon reflection, it is difficult to see how things could be otherwise. Positive institutional reform arises from voluntarily implementing policies that increase rulers' accountability to citizens and thereby secure citizens' rights and improve general economic well-being. If - as standard explanations claim - the resource curse arises from an institutional environment that encourages policy choices that disregard citizens' rights and general well-being, we have little reason to think that voluntary institutional reform is likely under those same institutional conditions.

As noted above, standard institutional stories make a conditional claim: states with unrestrictive institutions suffer the curse, while those with restrictive institutions can avoid the curse. But if the persistence of unrestrictive institutions is endogenous to the resource curse, then this conditional claim is too simple. A more subtle conditional claim is

The endogenous institutions thesis: If a country does not have firmly entrenched 
restrictive institutions before it becomes fiscally reliant on resource revenue, then its unrestrictive institutions will persist and it is vulnerable to the resource curse; if a country has firmly entrenched restrictive institutions before it becomes fiscally reliant on resource revenue, then it can avoid the resource curse.

This thesis consolidates those kept separate by the distinct economic and political resource curse claims, revealing them to be components of a single story. The economic resource curse strikes when institutions facilitate the misallocation of resource revenue in the domestic political economy; the political resource curse strikes when institutions permit the ruler to allocate revenue in a way that undermines accountability to a broad coalition of citizens. Unrestrictive institutions lie at the bottom of both of these phenomena. Institutions that permit rulers to undermine accountability mechanisms facilitate misallocation of resource revenues in the political economy. Hence, the resource curse is embodied by the persistence of unrestrictive institutions induced by fiscal reliance on resource revenue.

In the next section, I briefly review some models that are representative of the theoretical literature. Sections 4 and 5 present a theory to undergird the claim that curse-fostering institutions persist in the wake of continued resource dependence. I discuss the empirical implications of this theory in section 6 . This endogeneity claim has important implications for the efficacy of standard prescriptions to address the resource curse. I consider these briefly in a concluding section.

\section{FROM POLICY CHOICE TO INSTITUTIONAL DESIGN}

In this section, I show that extant theoretical models typically take as given the institutional setting into which resource revenue flows and then consider the effects this revenue has within the specified institutional structure.

Robinson, Torvik, and Verdier (2006) model an institutional setting where clientelism is permitted - that is, the ruler is permitted to offer public sector jobs in exchange for political support - and then show that resource booms increase clientelism. Since the private sector is assumed to be more productive than the public sector, these increases in public sector employment decrease overall economic productivity. Since resource booms improve extractive efficiency and thereby have a positive effect elsewhere in the economy, Robinson et al. conclude that institutional obstacles to clientelism play a key role. Institutions that facilitate clientelism make it more likely that resource booms will lower total income, while those that circumscribe clientelism will benefit from resource booms. 


\section{David Wiens}

Mehlum, Moene, and Torvik (2006) distinguish between grabber friendly institutions and producer friendly institutions - between institutions that encourage rent-seeking activity and those that encourage economically productive activity. To model the extent to which institutions are grabber friendly, they include a term $\lambda$, which measures producers' average share of the resource rents relative to grabbers' average share; a higher $\lambda$ means that institutions are producer friendly. Mehlum et al. then derive several key results. Not surprisingly, higher quality institutions - more producer friendly institutions - encourage more productive activity than lower quality institutions. Further, as resource revenue increases, institutional quality must improve to encourage productive activity and discourage rent-seeking. Finally, resource windfalls raise total income when institutional quality is high, but lower total income when institutional quality is low.

Wantchekon (2002) models an institutional setting where the ruler has discretionary control over the budget. When the risk of armed rebellion is low, the ruler uses resource revenue to secure political support rather than invest in economic productivity; when the risk of armed rebellion is high, the ruler invests in repressive technology to secure his rule. Wantchekon attributes an incumbency advantage to this control over the budget and uses this incumbency advantage to explain democratic breakdown and autocratic consolidation in resource dependent countries. Wantchekon concludes that institutions that enforce a transparent and rule-oriented distribution of resource revenue reduces the ruler's discretionary control over the budget and thereby improve democratic stability (cf. Caselli and Cunningham, 2009).

Each of these models treats (changes to) institutional quality as exogenous. They consider how resource revenue induces clientelism or rent-seeking or repression within a particular institutional environment. But notice that these types of behavior not only affect development outcomes - they also have a negative effect on institutions. Clientelistic public sector employment undermines the coherence and competence of the state bureaucracy, which in turn decreases the state's capacity to collect taxes and increases the ruler's discretionary control over the budget. Rent-seeking undermines a rational, principled budgetary process, which facilitates waste and corruption. Repression consolidates a ruler's power and alters the effective channels by which political power can change hands. All this raises a natural question: how does resource revenue affect the institutional environment that facilitates, for example, clientelism, rent-seeking, or repression? Failure to consider this question represents a significant shortcoming of the resource curse literature.

To fill this gap, I present a general model of domestic competition over political outcomes. In the model, groups of domestic constituents use whatever bargaining lever- 
age they have to induce the ruler to choose policies that advance their interests. When constituents lack bargaining leverage, the ruler is free to set policy as he sees fit; when constituents possess bargaining leverage, they are able to constrain the ruler's choices. My aim is to identify the conditions that determine constituents' bargaining strength. Since relative bargaining strength shapes political choice, the model identifies the underlying conditions to which choices (and, hence, development outcomes) are sensitive. The model reduces constituents' bargaining strength to two parameters: (1) the extent to which a ruler depends on constituents for (fiscal, political, military) support to retain political power; and (2) the credibility of supporters' exit threats (roughly, the extent to which they can quit negotiations with the ruler without harming themselves). Having shown that policy selection is sensitive to these parameters, I then theorize about how resource revenue affects them.

One advantage of my model is that it presents a single general framework for analyzing the effect of resource revenue on both institutional design and the policy choices made within any particular institutional setting. As I noted earlier, voluntary institutional reforms result from political choices. Citizens receive assurance that their ruler will protect their rights and promote their material well-being when institutional mechanisms are established to limit the ruler's discretion over policy. A ruler implements such limitations when he must. To elicit cooperation from citizens, a ruler commits himself to advance citizens' interests by limiting his discretion over policy. Importantly, institutions appear here as a choice variable - rulers and citizens can bargain over the future shape of their institutions. This permits us to study the effect of resource revenue on institutional design by examining the effect of resource revenue on the conditions that determine political choices more generally. But institutions also appear as a key determinant of citizens' relative bargaining leverage - existing institutions can affect the extent to which rulers depend on constituents for support and the credibility of constituents' exit options. To avoid confusion regarding this dual role of institutions as both a choice variable and a determinant of bargaining leverage, we should note that parties' bargaining leverage is a function of current institutions, while they negotiate over future institutions. (I elaborate this dual role at various points throughout the remaining sections).

\section{A MODEL OF POLITICAL COMPETITION}

4.1. Preliminaries The lesson we learn from institutional explanations of the resource curse is that the curse is avoided when restrictive institutions constrain rulers advance citizens' general interests. But restrictive institutions themselves emerge from protracted 


\section{David Wiens}

political negotiations between rulers and those they aspire to rule. We can thus treat the nature of institutions as a choice variable - rulers can choose to advance citizens' general interests by implementing restrictive institutions, or disregard their interests by implementing unrestrictive institutions. The salient question, then, is this: Under what conditions do rulers advance citizens' general interests?

Political rulers typically require support from some subset of their constituents to retain political power, be it as a source of revenue, votes, or military assistance to defeat a rival. To secure their support, rulers bargain with prospective supporters, offering policy concessions in exchange for the required support. To shed some light on the structural conditions underwriting these bargains, Clark et al. (2013) present a gametheoretic treatment of Hirschman's (1970) "Exit, Voice, and Loyalty" argument. Their model shows that a ruler is compelled to limit himself and provide public goods wherever two conditions are met. First, he depends on the cooperation of some group of citizens to consolidate and sustain his rule. Second, the citizens on whose cooperation the ruler depends have credible "exit threats"; that is, they can withhold their support without making themselves worse off than they would be were they to cooperate and provide the ruler with revenue. But this analysis obscures the fact that a ruler's need to respond to the demands of a group of citizens need not produce public goods. Political outcomes depend not only on the bargaining strength of citizens relative to the ruler, but also on the composition of the ruler's support coalition (Bueno de Mesquita et al., 2003). All else equal, the ruler is more likely to provide public goods - goods that advance citizens' interests in general - as (1) the number of people on whom the ruler depends for support increases, or (2) the credibility of the supporters' options for backing a leadership rival increases. ${ }^{4}$

The logic here is not complicated. Rulers want to retain power. Typically, they require the support of some subset of the population (the "winning coalition") to stay in power; without the loyal cooperation of their supporters, rulers are vulnerable to challenges from leadership rivals. Members of the winning coalition are drawn from a larger subset of the population, the "selectorate". The selectorate is composed of all members of a polity that could potentially become members of the ruler's winning coalition. In a democracy, the selectorate comprises all those who are eligible to vote; in a military junta, powerful military officers; in a monarchy, the nobles. Supporters pledge their allegiance to the leadership candidate who can credibly offer them the best package of benefits. To retain the loyalty of his supporters, a ruler provides them with a package of benefits that is

4 On the importance of the last point, see Clark et al. (2010). The last point is qualified in an important way below. 
better than the package they could expect to receive from a leadership rival. When a ruler depends on a small winning coalition, it is most efficient for him to provide his supporters with private goods - monopoly grants, public sector jobs, or opportunities for corruption. Since the ruler must retain the support of a relatively small group of people, and since the benefits of private goods can be targeted (i.e., they accrue only to the holder of the good), private goods provision is a relatively cheap way to provide a high value package of goods to supporters. However, as the size of the winning coalition grows, the ruler's spending must be spread over more supporters and the value of an individual's private goods package diminishes. At some point, the winning coalition becomes large enough that it is more efficient for the ruler to provide public goods - rule of law, individual liberties, infrastructure, or investment in human capital (e.g., education or public health) - rather than private goods. Although the benefits of public goods are nonexcludable (i.e., they accrue to everyone in the polity if they accrue to anyone) and so cannot be targeted to supporters, there are economies of scale in providing public goods, which enables a ruler to provide his supporters with a higher value package of public goods than the package of private goods that could be provided to each supporter for the same amount of total spending. Thus, a ruler becomes more inclined to provide public goods as the size of his support coalition grows, all else equal.

Similarly, in the absence of reliable sources of non-tax income (e.g., natural resources or foreign aid), a ruler becomes more likely to provide public goods as the credibility of his supporters' threats to back a rival increase, even if the absolute size of the winning coalition is small. More credible threats translate into greater bargaining leverage for supporters, which enables them to demand a greater package of private goods in exchange for their support. To meet the increasing demands of his supporters, a ruler must raise revenue to finance private goods provision. Without reliable sources of non-tax income, the ruler must turn his attention to increasing tax revenue. This means increasing the number of taxpayers or increasing the income of his tax base. A ruler can do both by fostering broad-based economic growth, which is most effectively and efficiently done by providing public goods rather than private goods. Consequently, absent reliable sources of non-tax revenue, a ruler becomes more inclined to provide public goods - albeit as a means to finance private goods provision - as the credibility of his supporters' threats to back a rival increases, all else equal (see Clark et al., 2010).

We can summarize the preceding discussion as follows. Wherever a ruler requires the (political, financial, military) support of a subset of the population to retain power and those supporters gain bargaining leverage from credible exit threats (e.g., asset mobility, private militias, credible leadership rivals), the supporters will be able to extract favorable 


\section{David Wiens}

concessions from the leader. Whether the benefits of those concessions accrue only to individual supporters or to citizens more widely depends on the composition of the ruler's support coalition - whether he only requires the support of a small group of elites or of a broad coalition of citizens - and the extent to which the leader must stimulate economic growth to finance his provision of goods.

This general picture emphasizes the importance of citizens' bargaining strength relative to the ruler in shaping political choices. But it neglects the importance of both the relative bargaining strength of distinct groups of citizens vis-a-vis the ruler and the relative value of their loyalty to the ruler. A ruler's choices depend not only on the bargaining strength of the ruler's supporters relative to the ruler, but also the bargaining strength of supporters vis-a-vis the ruler relative to the bargaining strength of other groups of citizens. Similarly, a ruler's choices depend not only on the value of supporters' loyalty to the ruler, but also the value of supporters' loyalty to the ruler relative to the value of other groups' loyalty to the ruler. ${ }^{5}$ To enhance our understanding of the conditions under which rulers advance citizens' interests, we must examine the logic of political choice when the ruler must negotiate with multiple groups, not simply with his supporters.

Before I present the model, though, it is worth pausing for a moment to highlight how the institutional status quo (among other factors) might shape constituents' relative bargaining position by affecting rulers' reliance on constituents' support or the availability of exit options. Ruler selection institutions offer an especially apt example here. If rulers are selected by electoral competition, then the institutional status quo ensures that citizens can withhold support from the incumbent by voting for a leadership challenger instead. Of course, whether such an exit option is credible depends on whether a challenger can credibly offer voters a better package of benefits than the one offered by the incumbent. This, too, is influenced by status quo institutions - e.g., whether existing institutions cultivate viable leadership contenders, reliably bind leadership contenders to abide by election results, and empower voters to hold election winners accountable for their campaign promises. In contrast, if rulers are selected by the military or the nobility instead, then the relevant military officers or nobles might have opportunities to withhold support for an incumbent by backing a coup, but ordinary citizens do not have similar exit options to those they would have under a stable electoral democracy. This contrast also shows how selection institutions affect the value of citizens' support to a ruler. In an electoral democracy, the ruler must elicit the support of a sufficient plurality of citizens; whereas, in a military regime or a monarchy, the ruler must elicit the support of only

5 Cf. "Not only the ruling class, but all classes whose resources and activities affected the preparation for war, left their imprint on European states" (Tilly 1992, 27; my emphasis). 
a small group of elites. Thus, existing institutions affect the number of people whose support is valuable. They also shape the identity of the people whose loyalty is potentially valuable. For instance, in a military regime or a monarchy, it might be that the capacity to make a difference to the ruler's survival probability is personalistic and restricted to a small number of elites; whereas, in an electoral democracy, rulers depend on largely anonymous supporters, so the capacity to affect the ruler's survival probability rarely depends on a voter's particular identity.

4.2. The Model Consider a game with three players who negotiate over control of an indivisible benefit, the value of which is normalized to 1 : a ruler $(R)$, who initially controls the benefit and sets policy to allocate the benefit; an elite class $(E)$ and a class of ordinary citizens $(C)$, each of whom attempt to obtain the benefit. ${ }^{6}$ I assume that the ruler's choice do not deliver any intrinsic benefit; that is, players do not care about the choice outcome for its own sake. Players' preferences over political choices are wholly determined by the material benefits they expect to receive as a consequence of any particular political choice. For instance, if the players are bargaining over how to spend a pot of government revenue, their preferences over allocative schemes are defined solely as a function of their expected payoff from implementing a particular allocative scheme. The benefit, thus, represents the material benefit to players as a consequence of the bargaining outcome. Since (future) institutions are treated as a choice variable here, the benefit represents the expected material benefit to players as a consequence of implementing the chosen institutional scheme.

The ruler makes his choice in pursuit of two aims: first, to ensure his retention of political power and, second, to maximize his material benefit. Following Bueno de Mesquita et al. (2003), I assume that the ruler provides public goods in exchange for citizens' cooperation, but private goods in exchange for elites' cooperation. ${ }^{7}$ He keeps everything for himself if he seeks neither elites' nor citizens' cooperation. Finally, I suppose that public goods provision advances citizens' interests generally, whereas private goods provision advances only the interests of their recipients and detracts from the interests of non-recipients.

Timeline. (1) The ruler chooses one of three available actions: he can neglect the interests

6 The model I present here is an extension of Clark, Golder, and Golder's (2013) "Exit, Voice, and Loyalty" model. I formalize the reasoning in the case where the ruler must negotiate with two civil society groups.

7 This assumption is also needed for the model to produce any interesting variation; if the ruler provides public (or private) goods regardless of his supporters' identity, the logic underlying the ruler's choice is obscured. 


\section{David Wiens}

of both the elites and the citizens (PREY); advance elites' interests by providing private goods (SUPPORT E); or advance citizens' interests by providing public goods (SUPPORT $C$ ). (2) Subsequent to the ruler's initial move, elites and citizens each choose one of the following actions simultaneously ${ }^{8}$ : to lobby the ruler for a favorable change at a cost $K>0$ (VOICE); to comply with the ruler's choice and absorb the consequences (LOYALTY); to take action to avoid the consequences of the ruler's choice (EXIT). If neither the elites nor the citizens use voice, the game ends and the players receive their payoffs. (3) If either the elites or the citizens use voice, the ruler subsequently advances the interests of a lobbying player (CONCEDE) or persists in implementing the initial choice (IGNORE). Since the ruler provides different packages of goods depending on whose cooperation he attempts to secure, the ruler can concede to only one of the two players if both elites and citizens exercise voice. If the ruler concedes to either player, the game ends and the players receive their payoffs. (4) If the ruler ignores any exercise of voice, then the player(s) who exercised voice either exit(s) or remain(s) loyal. If the ruler reverses a choice that is initially favorable for elites (citizens), then elites (citizens) either exit or remain loyal. The game ends and the players receive their payoffs.

Payoffs. If the ruler preys or both the elites and citizens exit, the ruler receives a benefit of 1 ; he receives 0 otherwise. If the elites remain loyal, the ruler receives an additional payoff $L_{E}>0$; if the citizens remain loyal, the ruler receives an additional payoff $L_{C}>0$. The ruler pays a cost $K_{R}>0$ if either the elites or the citizens use voice. If the ruler supports the elites and the latter remain loyal, then the elites receive 1 ; they receive 0 otherwise. If the elites exercise voice, they pay a cost $K_{E}>0$ and receive 1 if the ruler concedes and 0 if the ruler ignores. If the elites exit, they receive $X_{E}<1$. If the ruler supports citizens and the latter remain loyal, then the citizens receive 1 ; they receive 0 otherwise. If the citizens exercise voice, they pay a cost $K_{C}>0$ and receive 1 if the ruler concedes and 0 if the ruler ignores. If the citizens exit, they receive $X_{C}<1$. Elites and citizens lose any benefit they receive upon exercising an exit option.

Loyalty and exit elaborated. Constituents are loyal to the ruler when they support the ruler's efforts to retain power. Constituents express loyalty, in general, by not creating trouble for the ruler's efforts to consolidate his rule; this might mean paying taxes, voting for the incumbent, complying with the ruler's efforts to enforce a law, or taking up arms to defend the ruler against a military challenge. A player $i$ 's loyalty is valuable to the ruler

8 Although the timing of elites' and citizens' response to the ruler's initial choice doesn't matter. In all cases, at least one player has a (weakly) dominant response. 
to the extent that $i$ 's support makes a difference to the ruler's survival likelihood. If $i$ 's support makes a significant difference to the ruler's survival chances, then $i$ 's support is valuable; if $i$ 's support makes little difference to the ruler's survival chances, then $i$ 's support is not valuable. Formally, $i \in\{E, C\}$ has valuable loyalty when $L_{i}>1$.

Constituents exercise an exit option when they withdraw their support from the ruler's campaign to retain power. Examples of exit options include: the ability to move one's assets to avoid appropriation by the rule (e.g., via taxation or theft); the ability to instigate a coup or foment a revolution; the ability to emigrate; or the ability to back a leadership challenger in an election. A player $i$ 's threat to exercise an exit option is credible to the extent that the benefit $i$ expects to receive from the exit option is greater than the benefit $i$ expects to receive by remaining loyal to the ruler. If $i$ 's alternative to supporting the ruler has great expected value, then $i$ 's exit threats are credible; if $i$ 's alternative to supporting the ruler has little expected value, then $i$ 's exit threats are not credible. Formally, $i \in\{E, C\}$ has a credible exit threat when $X_{i}>0$.

I wish to note briefly that the loyalty and exit concepts used here are analytically independent: the credibility of $i$ 's exit threat does not depend on the value of $i$ 's loyalty to the ruler, nor does the value of $i$ 's loyalty depend on the credibility of $i$ 's exit threat. ${ }^{9}$ This is because the credibility of $i$ 's exit option is a function of the benefit $i$ expects to receive from an alternative to cooperating with the ruler, while the value of $i$ 's loyalty is a function of the ruler's survival probability given that $i$ withholds support. To illustrate the point, consider a high-ranking military officer whose support is crucial to the incumbent ruler's survival but who is sure to be ousted (or worse) by any viable challenger. This military officer's loyalty is valuable to the ruler but he lacks credible exit options. Or consider an anonymous voter who expects her interests will be better advanced by a challenger who must campaign against a widely popular incumbent. This voter has a credible exit threat (i.e., her threat to vote for the challenger is credible) but her loyalty is of little value to the incumbent.

Assumptions. I assume that elites and citizens will exit only if they have credible exit options; if $X_{i} \leq 0, i$ remains loyal. Similarly, elites and citizens will use voice only if $X_{i} \leq 1-K_{i}$; otherwise, they exit. I also assume that the ruler supports elites or citizens only if either has valuable loyalty. If both elites' and citizens' possess valuable loyalty, the ruler advances the interests of $i$ if $L_{i}>L_{j}$ for $i, j \in\{E, C\}$. To avoid knife-edge scenarios, I assume $L_{i} \neq L_{j}$.

9 Thanks to an anonymous reviewer for pressing me to clarify this point. 


\section{David Wiens}

I use backward induction to solve the game for the subgame perfect equilibrium. Since the point of the model is to determine the conditions under which rulers attend to citizens' interests, the main claims of interest concern the ruler's initial policy choice. These are stated below as propositions 1 and 2. But I start with a series of lemmas concerning equilibrium play in the various subgames; these are required to prove the propositions of interest. All proofs are relegated to the appendix.

I start with the subgame following an exercise of voice. Lemmas 1 and 2 characterize elites' and citizens' strategy for this subgame; lemma 3 characterizes the ruler's strategy for this subgame.

Lemma 1. For $i, j \in\{E, C\}, j \neq i$, if the ruler ignores $i$ or concedes to $j$ following $i$ 's use of voice, then (a) $i$ exits if $i$ has a credible exit option $\left(X_{i}>0\right)$; (b) $i$ remains loyal otherwise.

Lemma 2. For $i \in\{E, C\}$, if the ruler concedes to $i$ following $i$ 's use of voice, $i$ remains loyal.

Lemma 3. For $i \in\{E, C\}$, if $i$ uses voice, then:

(a) The ruler ignores $i$ if $i$ has no credible exit option $\left(X_{i} \leq 0\right)$.

(b) The ruler ignores $i$ if $i$ 's loyalty is not valuable despite having a credible exit option $\left(X_{i}>0\right.$ and $\left.L_{i} \leq 1\right)$. This is true except when $j \in\{E, C\}, j \neq i$ remains loyal following an initial policy of supporting $j$ and $j$ has no credible exit option $\left(X_{j} \leq 0\right)$ or $j$ 's loyalty is worth less than $i$ 's $\left(L_{j}<L_{i} \leq 1\right)$; then the ruler concedes to $i$.

(c) The ruler concedes to $i$ if $i$ 's loyalty is valuable and $i$ has a credible exit option $\left(X_{i}>0\right.$ and $\left.L_{i}>1\right)$. This is true except when $j \in\{E, C\}$ has a credible exit option and valuable loyalty $\left(X_{j}>0\right.$ and $\left.L_{j}>L_{i}\right)$ and either ( $i$ ) both $i$ and $j$ use voice, or (ii) $j$ is loyal following an initial policy of supporting $j$; then the ruler ignores $i$.

In words, the ruler concedes to $i$ 's use of voice whenever the ruler gains most from securing $i$ 's loyalty and $i$ has a credible exit option. The reasoning supporting this is straightforward. In view of $i$ 's credible exit option, the ruler must concede the benefit to secure $i$ 's loyalty - the ruler prefers to secure $i$ 's loyalty to retaining the benefit for himself because he requires $i$ 's support to retain political power. Otherwise, the ruler ignores any use of voice. If the ruler supports $i, i$ remains loyal; $i$ has no incentive to either exercise voice or exit, since both options are costly. If the ruler's neglect of $i$ 's interests and $i$ has a credible exit option, $i$ exits - remaining loyal in this case is more costly than exiting. In all other cases, $i$ remains loyal. 


\section{NATURAL Resources AND InSTItUtional DEVElopment}

Now consider how elites and citizens respond to each of the ruler's initial policy choices.

Lemma 4. For $i \in\{E, C\}$, if the ruler initially supports $i$, then $i$ remains loyal.

Lemma 5. For $i, j \in\{E, C\}$, if the ruler initially supports $j \neq i$, then:

(a) $i$ remains loyal if $i$ has no credible exit option $\left(X_{i} \leq 0\right)$.

(b) $i$ uses voice if doing so is less costly than exercising a credible exit option $\left(0<X_{i} \leq 1-K_{i}\right)$ and either $j$ has no credible exit option $\left(X_{j} \leq 0\right)$ or $i$ 's loyalty is worth more than $j$ 's $\left(L_{i}>L_{j}\right)$;

(c) $i$ exits otherwise.

Lemma 6. For $i \in\{E, C\}$, if the ruler initially preys, then

(a) $i$ remains loyal if $i$ has no credible exit option $\left(X_{i} \leq 0\right)$;

(b) $i$ uses voice if doing so is less costly than exercising a credible exit option $\left(0<X_{i} \leq 1-K_{i}\right)$ and securing $i$ 's loyalty benefits the ruler most $\left(L_{i}>\max \left\{1, L_{j}\right\}\right)$ or $i$ has valuable loyalty and it is more costly for $j$ to exercise voice than to exit $\left(L_{i}>1\right.$ and $\left.X_{j}>1-K_{j}\right)$ for $i \neq j \in\{E, C\}$;

(c) $i$ exits otherwise.

In words, $i$ is loyal if the ruler initially supports $i$ - exercising voice or an exit option are too costly, relative to the other options. If the ruler does not initially support $i, i$ remains loyal if $i$ has no credible exit option; $i$ exercises voice if doing so yields a greater benefit than exercising a credible exit option and is expected to win the ruler's support. The second condition is key. If $i$ knows that her use of voice will be ignored, she doesn't bother incurring the cost. In all other cases, $i$ exits in response to the ruler's lack of support.

The next two propositions turn to the matter of the ruler's initial policy choice in equilibrium in view of the preceding lemmas.

Proposition 1. The ruler preys (neglects both elites' and citizens' interests) if and only if elites and citizens lack either credible exit options or valuable loyalty; that is, iff $X_{i} \leq 0$ or $L_{i} \leq 1$ for $i \in\{E, C\}$. 


\section{David Wiens}

Proposition 2. The ruler supports citizens (elites) if and only if citizens (elites) have both a credible exit option and valuable loyalty and elites (citizens) either have no credible exit option or their loyalty is not valuable; that is, iff $X_{i}>0$ and $L_{i}>1$ and either $X_{j} \leq 0$ or $L_{j} \leq L_{i}$ for $i, j \in\{E, C\}, i \neq j$.

That proposition 1 is true given the setup of the model should be clear. When elites and citizens lack credible exit options, the ruler need not concede the benefit to secure their loyalty - they will remain loyal in any case. When elites and citizens lack valuable loyalty, the ruler has no incentive to concede the benefit; securing their cooperation is not required to achieve his aim.

The reasoning supporting proposition 2 follows straightforwardly from the preceding lemmas. If the ruler's aims are best served by securing $i$ 's loyalty, then the ruler wants to secure $i$ 's loyalty. If $i$ has a credible exit option, then the ruler must advance $i$ 's interests to secure $i$ 's loyalty (lemmas 5 and 6). If $i$ 's loyalty is valuable but less valuable then $j$ 's, then the ruler will have most reason to secure $j$ 's loyalty. But if $j$ has no credible exit option, the ruler has incentive to advance $i$ 's interests to elicit $i$ 's loyalty in addition to $j$ 's secure loyalty (lemma 5). If the ruler wishes to ultimately secure a player's loyalty, his initial choice preempts the use of voice by the player whose support he wishes to secure, since the ruler incurs a cost whenever elites or citizens exercise voice.

4.3. Discussion The strategic logic that governs the ruler's choice under these circumstances is the same as that in the case where the ruler negotiates with only one group of citizens, as in Clark et al. (2013). So it remains true that he must make concessions to any group whose support he requires to retain power and who have credible exit threats. Although they remain necessary conditions, citizens' possession of valuable loyalty and credible exit threats are no longer sufficient to produce public goods, as they are in the simpler case. To avoid outcomes where citizens' interests are harmed, it must also be true that either the elites have no credible exit options or their support is less valuable to the ruler for achieving his objectives than is the citizens'. If elites have credible exit options and their support is more valuable to the ruler than the citizens', then even if citizens have credible exit options and valuable loyalty, the ruler will provide private rather than public goods.

In sum, rulers advance citizens' general interests when two conditions are met. The first is a disjunctive requirement: either the ruler depends on the support of a broad coalition of citizens and elites have no exit options; or the leader depends more heavily on the support of a broad coalition of citizens to achieve his objectives than on the support of a small elite group. Second, the citizens whose support is required have credible exit 
options. When these conditions are satisfied, state rulers are constrained to advance citizens' general interests.

Where do institutions figure in all this? Recall the dual role assigned to institutions above: current institutions shape the players' relative bargaining position in the present; future institutions are the subject of present bargaining. Starting with the former, if current institutions ensure that citizens have high value exit options and that their loyalty is more valuable to the incumbent ruler than that of elites, then current institutions will ensure that citizens' relative bargaining leverage is such that the ruler makes policy choices that advance their general interests. Current institutions might bolster citizens' bargaining leverage by, for instance, ensuring that citizens in general have predominant influence over the selection rulers and that there will always be viable leadership challengers. However, if current institutions occlude citizens' alternatives to cooperating with the ruler or ensure that elites' loyalty is more valuable to the ruler, then current institutions will ensure that citizens' relative bargaining leverage is such that the ruler makes predatory policy choice or choices that advance elites' interests at the expense of citizens. Current institutions might undermine citizens' bargaining leverage by, for example, restricting the selectorate to a small group of elites or by ensuring that elites play a predominant role in shaping general election outcomes.

Turning now to institutions as a choice variable, suppose that players are bargaining in an unrestrictive institutional environment - there are no institutional mechanisms to ensure that the ruler's offers to prospective supporters are credible. Of course, if citizens do not have credible exit options or valuable loyalty, then the ruler can disregard their interests. However, if citizens have exit options - if they can credibly threaten to disengage from economic activity, or invest their money outside the ruler's jurisdiction, or threaten a revolution — and valuable loyalty — if citizens' taxes are a crucial source of the ruler's revenue, or the ruler lacks the capacity to put down a revolt - then (as above) the citizens' bargaining leverage is such that the ruler promises to advance their interests. But, since the ruler's promises are not credible here, rational citizens will discount the ruler's offer (thereby increasing the relative value of their exit options). Thus, rulers in an unrestricted institutional environment must solve a commitment problem to attract the necessary support from citizens with exit options. The ruler can raise the credibility of his offer by implementing restrictive institutions, which extend some control over future policy decisions to constituents in exchange for political support in the present (cf. Acemoglu and Robinson, 2006; Bates and Lien, 1985; Bueno de Mesquita et al., 2003; North and Weingast, 1989; Tilly, 1985; Weingast, 1997). 


\section{David Wiens}

\section{RESOURCE REVENUE AND POLITICAL CHOICE}

How does resource wealth affect the preceding logic? The most straightforward effect is to reduce the ruler's need to "earn" his income by reducing his reliance on tax revenue. In Mick Moore's words, "[s]tate revenue can be considered "earned" to the extent that the state apparatus has to put in organizational and political effort in working with citizens to get its money" (Moore, 2001:389). Simply, resource wealth reduces the ruler's need to put in effort to elicit cooperation from citizens to get his money. The importance of this point has been repeatedly stressed in case studies of the Arab gulf states - Bahrain, Kuwait, Qatar, Saudi Arabia, United Arab Emirates (Anderson, 1987; Beblawi, 1987; Chaudry, 1997) - Iran (Mahdavy, 1970), and Venzuela (Karl, 1997), as well as more general studies of the link between taxation and democratization (Ross, 2001, 2004). ${ }^{10}$

Section 4.2 shows just why a diminished need to tax is developmentally deleterious. When the ruler no longer depends on citizens as a source of revenue, he no longer needs to negotiate with citizens to secure their financial cooperation. The ruler retains discretion over the budget, which facilitates revenue misallocation throughout the economy (cf. Collier and Hoeffler, 2009; Wantchekon, 2002). The ruler can use resource revenue to finance consolidation of his rule and so fend off leadership challenges without requiring cooperation from citizens (at the polls, in arms, and so on). In terms of the theory sketched above, a ruler flush with resource revenue no longer depends on the citizens' fiscal support to finance his attempts to retain power. Hence, if they are not already present, he need not establish institutional mechanisms that grant citizens oversight of the policy formation process, such as representative bodies or a transparent budgetary process. More perniciously, where a ruler does not depend on the electoral support of a broad coalition of citizens to stay in office, he is freed from having to use resource revenue to secure wide electoral support. This permits him to retain more of the revenue for himself with impunity.

Relatedly, resource wealth frees the ruler from the need to foster economic growth to meet supporters' demands for goods (Bueno de Mesquita and Smith, 2010). As noted above, when a ruler relies on tax revenue to finance private goods provision, it is possible that the benefits of concessions to a small group of elites accrue to citizens more widely (see Clark et al., 2010). As North and Weingast (1989) argue, if elites' interests are served by concessions that foster widespread economic growth, such as secure property rights and the right to oversee taxation, then eventually citizens more generally come to benefit from the ruler's responsiveness to elites. But this possibility is diminished by

10 Herb (2005) registers tentative disagreement. 
fiscal reliance on resource wealth, which tends to encourage rent-seeking rather than productive activity (Baland and Francois, 2000; Tornell and Lane, 1999; Torvik, 2002). ${ }^{11}$ The benefits demanded by constituents in the context of resource dependence tend to be private rather than public in nature. The availability of resource revenue enables the ruler to meet these demands without needing to raise tax revenue and, thus, without needing to provide productivity-enhancing public goods. Without the need to foster broad-based economic growth, the ruler has little incentive to implement a rational budget process or establish a coherent development strategy.

Finally, resource wealth affects the availability of exit options. Oil wells and copper mines can't be moved. Consequently, when the ruler neglects the interests of resource holders, the latter can't force policy concessions by threatening to take their enterprise elsewhere. Even if their support is essential for political survival, resource holders are vulnerable to state predation due to a lack of credible exit options.

In general, the state's fiscal reliance on resource wealth generates a curse because it permits a ruler to consolidate his rule without needing to advance citizens' interests. The theory here comports with the central findings of the resource curse literature. ${ }^{12}$ When a ruler no longer needs citizens' money, he has no incentive to increase his tax base by fostering economic growth. This frees the ruler to use the revenue to pursue his personal aggrandizement or politically motivated "white elephant" projects rather than invest in human capital accumulation or sectoral diversification. Nor does he have any incentive to develop a rational and meritocratic bureaucracy, since he has no need to effectively collect taxes. This increases the ruler's discretionary power in policy-making, while freeing him to use public sector jobs as patronage to buy support. When a ruler no longer counts on citizens' political support, his performance is no longer subject to citizen oversight. This frees the ruler to pursue his own objectives by any means necessary with impunity.

So far, the story is a familiar one. But the model I have presented shows that the resource curse is more pernicious than previously thought. What makes the resource curse so difficult to overcome is the fact that the bargaining position afforded a ruler by resource wealth in an unrestrictive institutional environment undermines any incentive he might have to establish restrictive institutions, which are highly important for avoiding the resource curse. The resource curse is avoided when state rulers are constrained by institutional mechanisms that limit their use of resource revenue to financing initiatives that advance citizens' general interests, and enable citizens to remove them in the case of failure to do so. By undermining an unrestricted ruler's need to negotiate with citi-

11 See Bates (2008) and Karl (1997) for illustrative examples.

12 See the discussion in section 3. 


\section{David Wiens}

zens to consolidate his rule, resource wealth undermines a central impetus for positive institutional change. This is why it makes sense to refer to the resource curse as a trap. Once resource revenue is introduced into an unrestrictive institutional environment, it inhibits implementation of the institutional reforms needed to overcome the negative developmental effects of resource wealth. In other words, if, at the onset of resource dependence, a resource rich country has the unrestrictive institutions that engender the resource curse, then it is highly unlikely to establish the restrictive institutions that are so important to avoiding the curse.

In contrast, if restrictive institutions are in place at the onset of resource dependence, then there is no reason to expect resource revenues to precipitate a resource curse. Restrictive institutions generally ensure that citizens have credible exit threats and valuable loyalty. Hence, once the resource revenues begin to flow, the ruler will be constrained to use those revenues to advance citizens' general interests.

\section{EMPIRICAL IMPLICATIONS}

The theory I have presented implies the following claim:

If a country does not have firmly entrenched restrictive institutions before it becomes fiscally reliant on resource revenue, then its unrestrictive institutions will persist and it is vulnerable to the resource curse; if a country has firmly entrenched restrictive institutions before it becomes fiscally reliant on resource revenue, then it can avoid the resource curse.

If this claim is true, what should we observe empirically? To start, notice that an increase in fiscal reliance on resource income need not precipitate a decline in institutional quality and a decrease in fiscal reliance need not precipitate improvements in institutional quality. It is consistent with the theory I have presented that, following an increase in the state's fiscal reliance on resource revenue, institutional quality could: (1) remain the same; (2) decline; (3) improve (in the case where restrictive institutions precede the increased fiscal reliance). Thus, contrary to the assumption of most empirical studies - proponents and skeptics alike - we should not expect to find a systematic relationship between fiscal reliance on resource revenue and a country's level of democracy (Alexeev and Conrad, 2009; Aslaksen, 2010; Bueno de Mesquita and Smith, 2010; Dunning, 2008; Haber and Menaldo, 2011; Herb, 2005; Jensen and Wantchekon, 2004; Ramsay, 2011; Ross, 2001; Tsui, 2010). Instead, we should expect (1) resource dependence to be systematically related to a country's likelihood of establishing restrictive institutions, and (2) that this 
relationship is conditioned by the nature of a country's institutions prior to the onset of resource dependence. Resource dependent countries that start with unrestrictive institutions should be unlikely to establish restrictive institutions, whereas resource dependent countries that start with restrictive institutions should not be likely to lapse to unrestrictive institutions.

It is beyond the scope of this paper to provide systematic empirical evidence to support these expectations. ${ }^{13}$ Instead, I end with a brief consideration of the Venezuelan case, which might appear to contravene the expectations implied by the theory. According to Haber and Menaldo, Venezuela is one of seven countries that "democratized during or after a resource boom" (Haber and Menaldo, 2011:6). ${ }^{14}$ If it is true that Venezuela started with unrestrictive institutions and, after the onset of resource dependence, established institutional mechanisms to restrict their executives' discretion over policy formation and implementation - specifically, over the distribution of resource rents - then we have some evidence that my theory neglects some key considerations.

Cursory examination of the Venezuela case study literature strongly suggests that it is not a genuine counterexample - that in the wake of resource windfalls, Venezuela's institutions continued to afford their executives wide latitude over the distribution of resource revenue (among others, see Brewer-Carías, 2010; Corrales and Penfold, 2011; Crisp, 2000; Karl, 1997). In brief, from 1958 to 1999 (the period during which it was coded as a democracy), Venezuela's institutions were such that the president was usually the only elected official involved in the formation and implementation of policy. The president exercised discretion over appointments to consultative commissions and state agency governing boards, the main channels for policy formation and implementation. Since most state spending went through state agencies and state agencies' budgets were not

13 Morrison (2009); Smith (2004) find that resource revenues stabilize both autocracies and democracies; in contrast, Ross (2012) finds that resource revenues decrease the likelihood of democracy in both autocracies and democracies, while Clark et al. (2008:ch. 6) and Wiens et al. (2012) find that resource revenues decrease autocracies' likelihood of democratizing but have no effect on democracies' likelihood of remaining democratic (Al-Ubaydli 2012; Ulfelder 2007 also find that resource revenues decrease autocracies' likelihood of democratizing, but their studies omit democracies). Andersen and Aslaksen (2013); Bueno de Mesquita and Smith (2010); Cuaresma et al. (2011) find that resource revenues increase the likelihood of dictator survival. 14 The remaining six countries are: Botswana, Ecuador, Mexico, Mongolia, Peru, and Russia. According to Haber and Menaldo's coding rules, a country qualifies as democratic just in case it scores 7 or above on the Polity 2 measure; a country qualifies as resource dependent just in case an average of $5 \%$ of government revenues derived from resource extraction during the period from 1972 to 1999. Of the seven countries, Botswana is misclassified by Haber and Menaldo's lights - it was democratic from 1969 to 2007 but only became fiscally reliant on diamond revenues during the early 1970s. Mexico and Russia have been coded as democracies for a relatively short time (since 2000 and 2001 respectively) and Peru has not been stably democratic (1980-1991, 2000-present). 


\section{David Wiens}

subject to congressional oversight, the president was unaccountable in his distribution of resource revenue. Along with the ready availability of massive resource rents, Venezuela's institutions facilitated gross revenue misallocation. When oil prices collapsed in the early 1980s, the failure to cultivate broad tax extraction capacity left it without a domestic revenue base. But oil had cultivated unsustainable expectations. With its institutions too weak to rein in corruption, rent-seeking, and gross waste, Venezuela tapped international credit markets. This eventually precipitated a severe debt crisis, which led to the unravelling of Venezuela's "pacted democracy" and ushered in the era of Chàvismo.

Examination of the Venezuela case reveals an important lesson for future research on the resource curse. The resource curse is not about a lack of democratic institutions per se, but a lack of institutions that constrain rulers' discretion over the formation and implementation of policy. Democratic institutions are often restrictive institutions, as I define them. But, as the Venezuelan case demonstrates, they need not be; formally democratic institutions can be consistent with a largely unconstrained executive in practice. This cuts the other way too; restrictive institutions need not be democratic. Hence, potential counterexamples are not necessarily those countries that democratize during or following increased reliance on resource revenue. Instead, we must look for countries that appear to have begun with unrestrictive institutions prior to becoming resource dependent and subsequently established restrictive institutions. I leave this for future research.

\section{CONCLUDING REMARK}

The theory I have presented subtly but importantly amends standard institutional explanations of the resource curse. This amended theory says that a country's vulnerability to the resource curse is conditioned by the nature of its institutions prior to fiscal reliance on resources. If right, my theory has important prescriptive implications. Standard prescriptions call for resource-cursed countries to reform their domestic institutions to increase transparency and smooth spending so as to discourage corruption, revenue misallocation, and underinvestment. This prescriptive program is sustained by assuming away the possibility that continued reliance on resource revenue causes unrestrictive institutions to persist. Consider this offering from a recent collection of essays: "[we] assume throughout that both countries and companies can and should do something to more effectively and fairly develop oil resources. We assume in particular that governments are willing to take sometimes bold and difficult steps to succeed where most states have failed" (Humphreys et al., 2007: 14-15, emphasis added). This is clearly a consequential assumption: "[i]f states are unable or unwilling to take such steps, then the best solution may well be to 
leave the oil and gas in the ground" (Humphreys et al., 2007: 15). In other words, attempts to overcome the resource curse while governments that remain fiscally reliant on resource revenue are not willing to take "bold and difficult steps" to limit their discretion over the revenue are unlikely to be successful (cf. Kolstad and Wiig, 2009b).

The model I have presented undermines this critical assumption. It shows that leaders who are unresponsive to citizens-at-large prior to becoming fiscally reliant on resources have little incentive in the wake of resource windfalls to establish institutional mechanisms that increase their responsiveness to citizens' interests. Consequently, the resource curse is a much more stubborn problem than the standard prescriptive program supposes. The incentive structure posed by the combination of unrestrictive institutions and fiscal reliance on resources inhibits voluntary institutional reform.

Future prescriptive work must focus on improving citizens' bargaining power visa-vis rulers and elites. This requires finding ways to fulfill two conditions. First, future prescriptions must increase rulers' reliance on citizens for support. Perhaps the place to start is identifying ways to increase rulers' fiscal reliance on domestic income tax revenue. Second, future prescriptions must provide citizens' with credible exit options. Determining exactly how to best satisfy these conditions must be left for another time.

\section{APPENDIX}

Proof of Lemma 1. Suppose the ruler ignores $i$ or concedes to $j . U_{i}$ (loyalty) $=0$. Suppose $X_{i} \leq 0$. Then $U_{i}$ (exit) $=X_{i} \leq U_{i}$ (loyalty). So $i$ remains loyal.

Now suppose $X_{i}>0$. Then $U_{i}$ (exit) $\geq U_{i}$ (loyalty) and $i$ exits.

Proof of Lemma 2. Suppose the ruler concedes to $i$. Then $U_{i}$ (loyalty) $=1>U_{i}$ (exit) $=X_{i}$ (by assumption). So $i$ is always loyal if the ruler concedes.

Proof of Lemma 3. I prove each subitem separately.

(a) Suppose $X_{i} \leq 0$. Then $i$ remains loyal if ignored (by lemma 1). Thus, $U_{R}$ (concede) $=$ $L_{i} \leq U_{R}($ ignore $)=1+L_{i}$. So the ruler ignores $i$.

(b) Suppose $X_{i}>0$ and $L_{i} \leq 1$. Then $\min U_{R}$ (ignore) = 1 (by lemma 1), which is greater than $U_{R}($ concede $)=L_{i}$. So the ruler ignores $i$.

The preceding holds except in either of the following cases when $X_{i}>0$ and $L_{i} \leq 1$. Suppose $j$ remains loyal following SUPPORT $j$. 


\section{David Wiens}

Case 1. Suppose $X_{j} \leq 0$. Then $j$ is loyal when the ruler concedes to $i$ (by lemma 1). So $U_{R}($ concede to $i)=L_{i}+L_{j}-K_{R}>U_{R}($ ignore $i)=L_{j}-K_{R}$ (by lemmas 1 and 2). Thus, the ruler concedes to $i$.

Case 2. Suppose $L_{j}<L_{i}$. Whether $j$ exits or not, $\min U_{R}$ (concede to $\left.i\right)=L_{i}-K_{R}$ when the ruler concedes to $i$ (by lemma 2), whereas $U_{R}$ (ignore $\left.i\right)=L_{j}-K_{R}$ (by lemma 1 ). Since $L_{j}<L_{i}, U_{R}$ (concede to $\left.i\right)>U_{R}$ (ignore $i$ ). Thus, the ruler concedes to $i$.

(c) Suppose $X_{i}>0$ and $L_{i}>1$. Then $U_{R}($ ignore $i)=1-K_{R}<U_{R}($ concede to $i)=L_{i}-K_{R}$ (by lemmas 1 and 2). So the ruler concedes to $i$.

The preceding holds except in either of the following cases. Suppose (in addition) that $X_{j}>0$ and $L_{j}>L_{i}$.

Case 1. Suppose both $i$ and $j$ use voice. Then $U_{R}$ (concede to $\left.j\right)=L_{j}-K_{R}>$ $U_{R}($ concede to $i)=L_{i}-K_{R}>U_{R}$ (ignore) $=1-K_{R}$ (by lemmas 1 and 2). Thus, the ruler ignores $i$.

Case 2. Suppose $j$ is loyal following SUPPORT $j$. Then $U_{R}$ (ignore $\left.i\right)=L_{j}-K_{R}>$ $U_{R}($ concede to $i)=L_{i}-K_{R}$ (by lemmas 1 and 2). Thus, the ruler ignores $i$.

This concludes the proof.

Proof of Lemma 4. Let $s_{j}$ denote $j$ 's strategy for $i \neq j \in\{E, C\}$. $U_{i}$ (exit $\mid$ support $\left.i, s_{j}\right)=X_{i}$. Suppose the ruler supports $i$ in his initial policy choice. If $j$ uses voice following SUPPORT $i$, then the ruler can ignore $j$ or concede to $j$ (by lemma $3 \mathrm{~b}$ ).

Case 1. Suppose the ruler ignores $j$; then $U_{i}$ (loyalty $\left.\mid \operatorname{support} i, s_{j}\right)=1>$ $U_{i}$ (exit $\mid$ support $i, s_{j}$ ). So $i$ is loyal whenever the ruler supports $i$ and ignores $j$.

Case 2. Suppose the ruler concedes to $j$. If $X_{i} \leq 0, i$ remains loyal following CONCEDE TO $j$ and exits otherwise (by lemma 1). If $X_{i} \leq 0$, then

$$
U_{i}(\text { loyalty } \mid \text { support } i)=\left\{\begin{array}{ll}
0 & \text { if } j \text { uses voice } \\
1 & \text { if } j \text { exits or remains loyal }
\end{array} .\right.
$$

Since $U_{i}$ (exit $\mid$ support $\left.i, s_{j}\right) \leq 0, U_{i}$ (loyalty $\mid$ support $\left.i, s_{j}\right) \geq U_{i}$ (exit $\mid$ support $\left.i, s_{j}\right)$; so loyalty weakly dominates exit. Thus, if the ruler concedes to $j$ following $j$ 's use of voice and $X_{i} \leq 0, i$ responds to SUPPORT $i$ with loyalty whatever $j$ does. If $X_{i}>0$, then

$$
U_{i}(\text { loyalty } \mid \text { support } i)=\left\{\begin{array}{ll}
X_{i} & \text { if } j \text { uses voice } \\
1 & \text { if } j \text { exits or remains loyal }
\end{array}\right. \text {. }
$$


Again, $U_{i}$ (loyalty $\mid$ support $\left.i, s_{j}\right) \geq U_{i}$ (exit $\mid$ support $i, s_{j}$ ); so loyalty weakly dominates exit. Thus, if the ruler concedes to $j$ following $j$ 's use of voice and $X_{i}>0, i$ responds to SUPPORT $i$ with loyalty whatever $j$ does. Since $i$ is loyal whether $X_{i} \leq 0$ or $X_{i}>0, i$ responds to SUPPORT $i$ with loyalty whenever the ruler concedes to $j$ following $j$ 's use of voice.

Since $i$ is loyal whether the ruler concedes to $j$ or ignores $j$ following $j$ 's use of voice, $i$ is loyal whenever the ruler supports $i$.

Proof of Lemma 5. Suppose the ruler supports $j$ in his initial policy choice. By lemma 4, $j$ remains loyal.

(a) Then $U_{i}$ (loyalty) $=0$. Suppose $X_{i} \leq 0$. Then $U_{i}$ (exit) $=X_{i} \leq U_{i}$ (loyalty). So $i$ remains loyal.

(b) Now suppose $X_{i}>1-K_{i}$. Since $\max U_{i}$ (voice $\mid$ support $\left.j\right)=1-K_{i}$, $U_{i}$ (voice $\mid$ support $\left.j\right)<U_{i}$ (exit $\mid$ support $j$ ) and $i$ exits if the ruler supports $j$.

(c) Finally, suppose $0<X_{i} \leq 1-K_{i}$.

Case 1. Suppose $X_{j} \leq 0$. Then $j$ remains loyal if the ruler concedes to $i$ when $i$ uses voice (by lemma 1). Thus, $U_{i}$ (voice $\left.\mid \operatorname{support} j\right)=1-K_{i} \geq U_{i}$ (exit $\mid$ support $j$ ). So $i$ uses voice in response to SUPPORT $j$ if $0<X_{i} \leq 1-K_{i}$ and $X_{j} \leq 0$.

Case 2. Suppose $L_{i}>L_{j}$. Whether $j$ exits or not, the ruler concedes to $i$ (by lemma 3b, case 2). So $U_{i}$ (voice $\mid$ support $\left.j\right)=1-K_{i} \geq U_{i}$ (exit $\mid$ support $j$ ). So $i$ uses voice in response to SUPPORT $j$ if $0<X_{i} \leq 1-K_{i}$ and $L_{i}>L_{j}$.

Case 3. Suppose $X_{j}>0$ and $L_{j}>L_{i}$. Then the ruler ignores $i$ 's voice (by lemma 3c, case 2). Since $X_{i}>0$ (by assumption), $i$ exits if ignored and $U_{i}$ (voice $\mid$ support $j$ ) $=X_{i}-K_{i} \geq$ $U_{i}$ (exit $\mid$ support $\left.j\right)=X_{i}$. Thus, $i$ exits in response to SUPPORT $j$ if $0<X_{i} \leq 1-K_{i}$, $X_{j}>0$, and $L_{j}>L_{i}$.

This concludes the proof.

Proof of Lemma 6. Suppose the ruler preys in his initial policy choice. Then $U_{i}$ (loyalty) $=$ 0.

(a) Suppose $X_{i} \leq 0$. Then $U_{i}$ (exit) $=X_{i} \leq U_{i}$ (loyalty). So $i$ remains loyal if $X_{i} \leq 0$.

(b) Now suppose $X_{i}>1-K_{i}$. Since $\max U_{i}$ (voice $\mid$ prey $)=1-K_{i}, U_{i}$ (voice $\mid$ prey $)<$ $U_{i}$ (exit | prey) and $i$ exits if $X_{i}>1-K_{i}$. 


\section{David Wiens}

(c) Now suppose $0<X_{i} \leq 1-K_{i}$. Let $s_{j}$ denote $j$ 's strategy.

Case 1. Suppose $L_{i}>\max \left\{1, L_{j}\right\}$. By lemma 3c, the ruler concedes to $i$ if $i$ uses voice. Thus, $U_{i}$ (voice $\mid$ prey, $\left.s_{j}\right)=1-K_{i} \geq U_{i}$ (exit $\mid$ prey, $\left.s_{j}\right)>U_{i}$ (loyalty $\mid$ prey). So $i$ uses voice if $0<X_{i} \leq 1-K_{i}$ and $L_{i}>\max \left\{1, L_{j}\right\}$.

Case 2. Suppose $L_{i}>1$ and $X_{j}>1-K_{j}$. Consequently, $j$ exits if the ruler preys (by lemma 6b) and the ruler concedes to $i$ if $i$ uses voice (by lemma 3c). Thus, $U_{i}\left(\right.$ voice $\mid$ prey, $s_{j}=$ exit $)=1-K_{i} \geq U_{i}$ (exit $\mid$ prey, $s_{j}=$ exit $)>U_{i}$ (loyalty $\mid$ prey, $s_{j}=$ exit). So $i$ uses voice if $0<X_{i} \leq 1-K_{i}, L_{i}>1$, and $X_{j}>1-K_{j}$.

Case 3. Suppose $L_{j}>L_{i}>1$ and $0<X_{j} \leq 1-K_{j}$. Consequently, $j$ uses voice (by lemma $6 \mathrm{c}$, case 1 ) and the ruler concedes to $j$ (by lemma 3c). Thus, $U_{i}$ (voice $\mid$ prey, $s_{j}=$ voice $)=X_{i}-K_{i} \leq U_{i}$ (exit $\mid$ prey, $s_{j}=$ voice) and $U_{i}$ (loyalty $\mid$ prey, $s_{j}=$ voice $)=0<$ $U_{i}$ (exit $\mid$ prey, $s_{j}=$ voice). So $i$ exits if $0<X_{i} \leq 1-K_{i}, L_{j}>L_{i}>1$, and $0<X_{j} \leq 1-K_{j}$.

Case 4. Suppose $L_{i} \leq 1$. Then the ruler ignores $i$ (by lemma 3b). Thus, $U_{i}\left(\right.$ voice $\mid$ prey, $\left.s_{j}\right)=X_{i}-K_{i} \leq U_{i}$ (exit $\mid$ prey, $s_{j}=$ voice) and $U_{i}$ (loyalty $\mid$ prey, $s_{j}=$ voice $)=0<U_{i}$ (exit $\mid$ prey, $s_{j}=$ voice $)$. So $i$ exits if $0<X_{i} \leq 1-K_{i}$ and $L_{i} \leq 1$.

This concludes the proof.

Proof of Proposition 1. If: Case 1. Suppose $X_{i} \leq 0$ for all $i \in\{E, C\}$. Then $i$ remains loyal whatever the ruler does (by lemmas 4 , 5a, 6a). Thus, $U_{R}$ (prey) $=1+L_{E}+L_{C}>$ $U_{R}($ support $i)=L_{i}+L_{j}$. So the ruler preys.

Case 2. Suppose $X_{i} \leq 0<X_{j}$ and $L_{j} \leq 1$ for $i \neq j \in\{E, C\}$. Then $i$ remains loyal whatever the ruler does (by lemmas $4,5 \mathrm{a}$, and 6a). Further, $j$ exits in response to PREY (by lemma $6 \mathrm{~b}$ and c, case 4) or SUPPORT $i$ (by lemma $5 \mathrm{~b}$ and c, case 3 ) but remains loyal when SUPPORT $j$ (by lemma 4). Thus, $U_{R}$ (prey) $=1+L_{i} \geq U_{R}($ support $j)=L_{i}+L_{j}>U_{R}($ support $i)=L_{i}$. So the ruler preys.

Case 3. Suppose $X_{i}>0$ and $L_{i} \leq 1$ for all $i \in\{E, C\}$. Then $i$ exits in response to PREY (by lemma $6 \mathrm{~b}$ and c, case 4 ) or SUPPORT $j$ (by lemma $5 \mathrm{~b}$ and c, case 3 ) but remains loyal when SUPPORT $i$ (by lemma 4). Thus, $U_{R}$ (prey) $=1 \geq U_{R}$ (support $i$ ) $=L_{i}$. So the ruler preys.

Since the ruler preys in all cases, the ruler preys if $X_{i} \leq 0$ or $L_{i} \leq 1$.

Only If: Suppose the ruler preys. Prove the contrapositive to show a contradiction. Suppose it's not the case that $X_{i} \leq 0$ or $L_{i} \leq 1$ for $i \in\{E, C\}$. By De Morgan's law, $X_{i}>0$ and $L_{i}>1$. It follows from lemmas $1,2,3$, and 6 that $\max U_{R}$ (prey) $=\max \left\{L_{i}-K_{R}, 1\right\}$. It follows from lemma 4 that $\min U_{R}$ (support $\left.i\right)=L_{i}$. Since $L_{i}>1$ by assumption, $\min U_{R}$ (support $\left.i\right)>\max U_{R}$ (prey). So the ruler supports $i$. Thus, we get a contradiction by assuming $X_{i}>0$ and $L_{i}>1$. Hence, if the ruler preys, either $X_{i} \leq 0$ or $L_{i} \leq 1$. 


\section{NATURAL Resources AND Institutional DeVELopment}

Proof of Proposition 2. If: Suppose $X_{i}>0$ and $L_{i}>\max \left\{1, L_{j}\right\}$. Then $i$ exits in response to PREY (by lemma $6 \mathrm{~b}$ and c, case 4 ) or SUPPORT $j$ (by lemma $5 \mathrm{~b}$ and c, case 3 ) but remains loyal when SUPPORT $i$ (by lemma 4).

Case 1. Suppose $X_{j} \leq 0$. Then $j$ remains loyal whatever the ruler does (by lemmas 4 , 5a, and 6a). Thus, $U_{R}$ (support $\left.i\right)=L_{i}+L_{j}>U_{R}$ (prey) $=1+L_{j}>U_{R}($ support $j)=L_{j}$. So the ruler supports $i$ if $X_{i}>0$ and $L_{i}>1$ and $X_{j} \leq 0$.

Case 2. Suppose $X_{j}>0$ and $L_{i}>\max \left\{1, L_{j}\right\}$. Then $j$ exits in response to PREY (by lemma $6 \mathrm{~b}$ and c, case 4) or SUPPORT $i$ (by lemma 5b and c, case 3) but remains loyal when SUPPORT $j$ (by lemma 4 ). Thus, $U_{R}$ (support $\left.i\right)=L_{i}>\max \left\{U_{R}(\right.$ support $j)=$ $L_{j}, U_{R}($ prey $\left.)=1\right\}$. So the ruler supports $i$.

Since the ruler supports $i$ in all cases, the ruler supports $i$ if $X_{i}>0, L_{i}>1$ and either $X_{j} \leq 0$ or $L_{j} \leq L_{i}$.

Only If: Suppose the ruler supports some $i \in\{E, C\}$. Prove the contrapositive to show a contradiction. Suppose it's not the case that $X_{i}>0$ and $L_{i}>1$ and either $X_{j} \leq 0$ or $L_{j} \leq L_{i}$ for $i \neq j \in\{E, C\}$. By De Morgan's law, either it's not the case that $X_{i}>0$ and $L_{i}>1$ or it's not the case that $X_{j} \leq 0$ or $L_{j} \leq L_{i}$ for $i \neq j \in\{E, C\}$.

Case 1. Suppose it's not the case that $X_{i}>0$ and $L_{i}>1$ for some $i \in\{E, C\}$. By De Morgan's law, $X_{i} \leq 0$ or $L_{i} \leq 1$. We can ignore $j$ 's action, so the ruler receives $L_{j} \in\{0, x\}$ for $x \in \mathfrak{R}$. If $X_{i} \leq 0$, it follows from lemma 6 that $\min U_{R}$ (prey) $=1+L_{i}+L_{j}$ and from lemma 4 that $\max U_{R}$ (support $\left.i\right)=L_{i}+L_{j}$ for all $i \in\{E, C\}$. Since $\min U_{R}$ (prey) > $\max U_{R}$ (support $i$ ), the ruler preys if $X_{i} \leq 0$. If $L_{i} \leq 1$, it follows from lemma 6 that $\min U_{R}$ (prey) $=1+L_{j}$ and from lemma 4 that $\max U_{R}$ (support $\left.i\right)=L_{i}+L_{j}$ for all $i \in\{E, C\}$. Since $\min U_{R}$ (prey) $>\max U_{R}$ (support $i$ ), the ruler preys if $L_{i} \leq 1$. Hence, the ruler preys if $X_{i} \leq 0$ or $L_{i} \leq 1$.

Case 2. Suppose it's not the case that $X_{j} \leq 0$ or $L_{j} \leq L_{i}$ for $i \neq j \in\{E, C\}$. By De Morgan's law, $X_{j}>0$ and $L_{j}>L_{i}$. If $L_{j}>1$, it follows from the "If" part of this proof that the ruler supports $j$. Now hold $i$ 's action constant, so the ruler receives $L_{i} \in\{0, x\}$ for $x \in \mathfrak{R}$. If $L_{j} \leq 1$, then it follows from lemma 6 that $\min U_{R}$ (prey) $=1+L_{i}$ and from lemmas 3-5 that $\max U_{R}($ support $j)=\max U_{R}$ (support $\left.i\right)=L_{j}+L_{i}$. Since $\min U_{R}$ (prey) $>\max U_{R}$ (support $i$ ), the ruler preys if $L_{j} \leq 1$. Thus, the ruler does not support $i$ if $X_{j}>0$ and $L_{j}>L_{i}$.

In either case, the ruler does not support $i$. Thus, we get a contradiction by proving the contrapositive. Hence, if the ruler supports $i$, then $X_{i}>0$ and $L_{i}>1$ and either $X_{j} \leq 0$ or $L_{j} \leq L_{i}$ for $i \neq j \in\{E, C\}$. 
David Wiens

\section{REFERENCES}

Acemoglu D and Robinson JA (2006) Economic Origins of Dictatorship and Democracy. New York: Cambridge University Press.

Al-Ubaydli O (2012) Natural resources and the tradeoff between authoritarianism and development. Journal of Economic Behavior and Organization 81(1): 137-152.

Alexeev M and Conrad R (2009) The elusive curse of oil. The Review of Economics and Statistics 91(3): 586-598.

Andersen J and Aslaksen S (2008) Constitutions and the resource curse. Journal of Development Economics 87: 227-246.

Andersen J and Aslaksen S (2013) Oil and political survival. Journal of Development Economics 100(1): 89-106.

Anderson L (1987) The state in the Middle East and North Africa. Comparative Politics 20(1): 1-18.

Aslaksen S (2010) Oil and democracy: more than a cross-country correlation? Journal of Peace Research 47(4): 421-431.

Auty R (ed) (2001) Resource Abundance and Economic Development. New York: Oxford University Press.

Baland JM and Francois P (2000) Rent-seeking and resource booms. Journal of Development Economics 61: 527-542.

Bates RH (2008) When Things Fell Apart: State Failure in Late-Century Africa. New York: Cambridge University Press.

Bates RH and Lien DHD (1985) A note on taxation, development, and representative government. Politics \& Society 14(1): 53-70.

Beblawi H (1987) The rentier state in the Arab world. In: Beblawi H and Luciani G (eds) The Rentier State: Nation, State and the Integration of the Arab World. London: Croom Helm.

Bell J, Collier P, Conrad R, Heller T, Lissakers K, Ross M, Spend M, and Venables A (2010) Natural resource charter. URL: http://www.naturalresourcecharter.org.

Bhattacharyya S and Hodler R (2010) Natural resources, democracy, and corruption. European Economic Review 54: 608-621. 
Boschini AD, Pettersson J, and Roine J (2007) Resource curse or not: a question of appropriability. Scandanavian Journal of Economics 109(3): 593-617.

Brewer-Carías AR (2010) Dismantling Democracy in Venezuela: The Chávez Authoritarian Experiment. New York: Cambridge University Press.

Bueno de Mesquita B and Smith A (2010) Leader survival, revolutions, and the nature of government finance. American Journal of Political Science 54(4): 936-950.

Bueno de Mesquita B, Smith A, Siverson RM, and Morrow JD (2003) The Logic of Political Survival. Cambridge, MA: MIT Press.

Caselli F and Cunningham $\mathrm{T}$ (2009) Leader behaviour and the natural resource curse Oxford Economic Papers 61(4): 628-650.

Chaudry KA (1997) The Price of Wealth: Economies and Institutions in the Middle East. Ithaca and London: Cornell University Press.

Clark WR, Golder M, and Golder S (2013) Power and politics: insights from an exit, voice, and loyalty game. Manuscript, University of Michigan and Penn State University.

Clark WR, Golder M, and Golder SN (2008) Principles of Comparative Politics. Washington, D.C.: CQ Press.

Clark WR, Poast P, Flores T, and Kaufman RR (2010) Why do autocrats overachieve? political competition and material well-being in comparative perspective. Mimeo, University of Michigan and Rutgers University.

Collier P and Hoeffler A (2009) Testing the neocon agenda: democracy in resource-rich countries. European Economic Review 53: 293-308.

Corrales J and Penfold M (2011) Dragon in the Tropics: Hugo Chávez and the Political Economy of Revolution in Venezuela. Washington, D.C.: Brookings Institution Press.

Crisp BF (2000) Democratic Institutional Design: The Powers and Incentives of Venezuelan Politicians and Interest Groups. Stanford: Stanford University Press.

Cuaresma JC, Oberhofer H, and Raschky PA (2011) Oil and the duration of dictatorships. Public Choice 148: 505-530.

Dunning T (2008) Crude Democracy: Natural Resource Wealth and Political Regimes. New York: Cambridge University Press. 


\section{David Wiens}

Gelb A and Associates (1988) Oil Windfalls: Blessing or Curse? New York: Oxford University Press.

Haber S and Menaldo V (2011) Do natural resources fuel authoritarianism? a reappraisal of the resource curse. American Political Science Review 105(1): 1-26.

Herb M (2005) No representation without taxation? rents, development, and democracy. Comparative Politics 37(3): 297-316.

Hirschman AO (1970) Exit, Voice, and Loyalty: Responses to Declines in Firms, Organizations, and States. Cambridge, MA: Harvard University Press.

Humphreys M, Sachs JD, and Stiglitz JE (eds.) (2007) Escaping the Resource Curse New York: Columbia University Press.

Jensen N and Wantchekon L (2004) Resource wealth and political regimes in Africa. Comparative Political Studies 37(7): 816-841.

Karl TL (1997) The Paradox of Plenty: Oil Booms and Petro-States. Berkeley and Los Angeles: University of California Press.

Kolstad I and Wiig A (2009a) Is transparency the key to reducing corruption in resourcerich countries? World Development 37(3): 521-532.

Kolstad I and Wiig A (2009b) It's the rents, stupid! the political economy of the resource curse. Energy Policy 37: 5317-5325.

Le Billon P (2001) The political ecology of war: natural resources and armed conflicts. Political Geography 20: 561-584.

Mahdavy H (1970) The patterns and problems of economic development in rentier states: the case of Iran. In: Cook MA (ed) Studies in Economic History of the Middle East. London: Oxford University Press.

Mehlum H, Moene K, and Torvik R (2006) Institutions and the resource curse. The Economic Journal 116(1): 1-20.

Moore M (2001) Political underdevelopment: what causes "Bad Governance"? Public Management Review 3(3): 385-418.

Morrison KM (2007) Natural resources, aid, and democratization: a best-case scenario. Public Choice 131: 365-386. 
Morrison KM (2009) Oil, nontax revenue, and the redistributional foundations of regime stability. International Organization 63: 107-138.

North DC and Weingast B (1989) Constitutions and commitment: the evolution of institutions governing public choice in seventeenth-century England. Journal of Economic History 49(4): 803-832.

Ramsay KW (2011) Revisiting the resource curse: natural disasters, the price of oil, and democracy. International Organization 65: 507-529.

Robinson JA, Torvik R, and Verdier T (2006) Political foundations of the resource curse. Journal of Development Economics 79(2): 447-468.

Ross ML (2001) Does oil hinder democracy? World Politics 53: 325-361.

Ross ML (2004) Does taxation lead to representation? British Journal of Political Science 34(2): 229-249.

Ross ML (2012) The Oil Curse: How Petroleum Wealth Shapes the Development of Nations. Princeton and Oxford: Princeton University Press.

Sachs JD and Warner AM (2001) The curse of natural resources. European Economic Review 45: 827-838.

Smith B (2004) Oil wealth and regime survival in the developing world, 1960-1999. American Journal of Political Science 48(2): 232-246.

Smith B (2006) The wrong kind of crisis: why oil booms and busts rarely lead to authoritarian breakdown. Studies in Comparative International Development 40(4): 55-76.

Snyder R and Bhavnani R (2005) Diamonds, blood, and taxes: a revenue-centered framework for explaining political order. Journal of Conflict Resolution 49(4): 563-597.

Tilly C (1985) War making and state making as organized crime. In: Evans P, Rueschemeyer D, and Skocpol T (eds) Bringing the State Back In. Cambridge: Cambridge University Press.

Tilly C (1992) Coercion, Capital, and European States, AD 990-1992. 2nd ed. Malden, MA: Blackwell.

Tornell A and Lane PR (1999) The voracity effect. American Economic Review 89(1): 22-46.

Torvik R (2002) Natural resources, rent seeking, and welfare. Journal of Development Economics 67: 455-470. 


\section{David Wiens}

Tsui KK (2010) More oil, less democracy: evidence from worldwide crude oil discoveries. The Economic Journal 121: 89-115.

Ulfelder J (2007) Natural-resource wealth and the survival of autocracy. Comparative Political Studies 40(8): 995-1018.

Wantchekon L (2002) Why do resource abundant countries have authoritarian governments? Journal of African Finance and Economic Development 5(2): 57-77.

Weingast BR (1997) The political foundations of democracy and the rule of law. American Political Science Review 91(2): 245-263.

Wiens D, Poast P, and Clark WR (2012) The political resource curse: an empirical reevaluation. Manuscript, Australian National University and Rutgers University.

Williams A (2011) Shining a light on the resource curse: an empirical analysis of the relationship between natural resource, transparency, and economic growth. World Development 39(4): 490-505. 